\title{
Is Barter a Hobson Choice? \\ A Theory of Barter and Credit Rationing
}

José Noguera

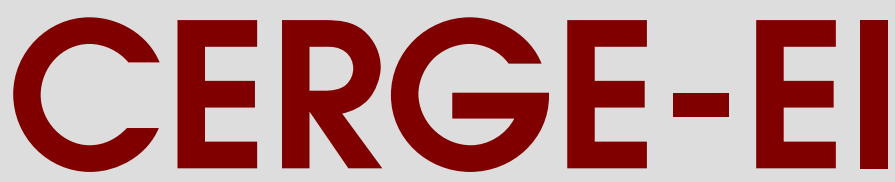

Charles University Center for Economic Research and Graduate Education Academy of Sciences of the Czech Republic Economics Institute

WORKING PAPER SERIES (ISSN 1211-3298) Electronic Version 


\title{
IS BARTER A HOBSON'S CHOICE?
}

A theory of barter and credit rationing

\author{
José Noguera \\ CERGE-EI
}

September 2004

\section{Contact Information:}

Jose Noguera, P.O. Box 882, Politických věžnů 7, 11121 Prague 1, Czech Republic, phone (420-2) 240.05.107, e-mail: Jose.Noguera@cerge.cuni.cz 


\title{
IS BARTER A HOBSON'S CHOICE?
}

\section{A theory of barter and credit rationing}

\begin{abstract}
$\underline{\text { Abstract }}$
This paper proposes a theoretical monetary model to inquire as to whether the growth and decline in barter transactions between firms in Russia during the 1990s was the result of credit rationing or firms' optimal decision. The model also provides an explanation for the negative correlations between the share of total transactions between firms conducted through barter and inflation, and also to the quick decline in barter transactions that followed the 1998 currency crisis.
\end{abstract}

\begin{abstract}
$\underline{\text { Abstrakt }}$
Teoretický monetárny model, navrhnutý v tejto práci, skúma, či rast a následný pokles využívania výmenného obchodu medzi podnikmi v Rusku v rokoch 1990-2000 boli dôsledkom obmedzenia dostupnosti úverových zdrojov (credit rationing) alebo dôsledkom optimalizácie rozhodovacieho procesu podnikov. Skúmaný model predkladá vysvetlenie negatívnej korelácie medzi mierou inflácie a podielom výmenného obchodu v celkovom objeme firemných transakcií. Model tiež vysvetl'uje rýchly úpadok využívania výmenného obchodu po menovej kríze v roku 1998.

Kl'účové slová: výmenný obchod, úroková miera, optimálne rozhodovanie
\end{abstract}

JEL: E0, E4, E5, F41, P24, P26

Keywords: Barter, interest rate, credit rationing, optimal choice.

This research was supported by a Grant from the CERGE-EI Foundation under a Program of the Global Development Network. All opinions expressed are those of the author and have not been endorsed by CERGE-EI or the GDN. 


\section{IS BARTER A HOBSON'S CHOICE?}

\section{A theory of barter and credit rationing}

\section{INTRODUCTION}

Barter transactions have usually been seen as an expensive, peculiar process that must be dominated by money. The literature on search and money that began with Kiyotaki and Wright $(1989,1993)$ and Trejos and Wright (1991) aims to explain the inefficiencies of bartering and why it must be dominated by money. Gaddy and Ickes (1999) and Hendley et al (2000) argue that in some CIS countries, firms choose barter to evade the official economy, thus hindering efforts to both restructure the economy and develop efficient market relations; and Blanchard and Kremer (1997) claim that barter in Russia is the result of disorganization. However, barter has always been around. Kindleberger (1993) documents many cases in history where people have substituted tender for other stronger currencies, primitive money or simple barter. Barter transactions represent a significant share of total transactions even in modern economies. ${ }^{1}$ Time magazine (February 5, 2002), for instance reported on how barter has replaced the cash economy for many Argentineans. Recently, there has been increasing barter activity worldwide. According to the International Reciprocal Trade Association (IRTA), firms from 25 countries participate in more than 500 organized exchange or barter companies worldwide, most of them in the United States, trading a great diversity of goods and services for an amount estimated in the USD 7.5 billions during 2001 alone. The IRTA also conducted a survey

\footnotetext{
${ }^{1}$ See Ellingsen and Stole (1996) and Marin and Schnitzer (1995).
} 
among firms and concluded that the optimal number of barter transactions should be about $4 \%$ of total transactions. ${ }^{2}$ Barter is clearly still an exchange technology available even in modern societies.

Prendergast and Stole (1999, 2001a, and 2001b) claim that barter exists because firms use it as a means of market segmentation to increase their profits. This story rests on structural factors to justify the existence of barter and seems a suitable explanation in a stable monetary environment. However, in the presence of monetary instability, we may find other reasons for barter's persistence. Inflation has traditionally been a main cause for bartering in unstable economies. Nevertheless, barter in Russia increased while there was disinflation. In fact, using monthly data from February 1992 to June 2002, Table 1 shows significant negative correlations according to Spearman's test between barter transactions as the share of total transactions and the money growth rate and the inflation rate in Russia (Stylized Fact 1). Figure 1 reveals another interesting fact: barter in industrial sales grew in Russia from 5-10\% of total transactions in 1992 and reached a 54\% peak in August 1998, exactly one month before the collapse of the ruble in September 1998; from that date on, it has declined continuously to a point close to its initial level (Stylized Fact 2).

There is abundant empirical literature proposing either liquidity shortage or credit constraint as possible explanations for the rise and fall of barter in Russia. ${ }^{3}$ But liquidity shortage argument does not seem an appropriate explanation in an economy with a two or three-digit money growth rate, as was the case of Russia during the 1990s.

\footnotetext{
${ }^{2}$ See the International Reciprocal Trade Association web page, www.irta.com.

${ }^{3}$ See Bevan et al (2001), Brana and Maurel (2000), Commander et al (2000), Ellingsen (1998), Linz and Krueger (1998), Makarov and Kleiner (2000), and Marin and Schnitzer (1999).
} 
On the other hand, in the literature that started with Keeton (1979) and Stiglitz and Weiss (1981), the main reason for credit rationing is that, as the credit market becomes tighter, the safest borrowers quit the market, making it even riskier. Credit rationing thus appears since lenders do not satisfy the demand for loans to hedge themselves against the increasing risk. Rationed firms then choose to barter if that technology is available. In this case, barter is a Hobson's choice. Yet, would it be optimal for firms to choose to barter before being subject to credit rationing? In other words, is barter the result of firms' optimal decision or is it a Hobson's choice? There is no formal theory providing links between the credit rationing and barter literatures to answer this question, so using the experience of Russia during the 1990s as motivation, this paper proposes a model to ascertain whether barter is the result of firms' optimal decision or is a Hobson's choice. The model also provides an explanation for the two stylized facts mentioned above. Section II provides a discussion about barter. Section III presents the model and analyzes its operation. Section IV uses that model to explain the main stylized facts about the Russian economy discussed above, and Section V concludes.

\section{BARTER TRANSACTIONS}

Barter is defined as the trading of goods or services without the exchanging of money, for example, an exchange of apples for bananas. This kind of transactions occurred frequently in primitive times and in the episodes mentioned in the introduction. The barter transactions registered by the International Reciprocal Trade Association (IRTA) are usually settled through a huge computer network that facilitates the exchange without the need of using money. Once the double coincidence is established, or a series of transactions is assigned, a number of transactions occur, that is, firms barter. Firms 
belonging to one of these barter networks finance the acquisition of a share of their input needs this way, and the remainder by conventional monetary transaction methods.

The case of bartering in Russia is somehow of a different vintage. As in the previous case, double coincidence of wants often occurred, many "barter chains" also appeared, but instead of using a computer network, firms frequently hire directors to arrange for those transactions. ${ }^{4,5}$ Yet, unlike transactions registered by IRTA, some goods were frequently accepted as media of exchange: cigarettes, vodka, electronic equipment, and cars were widely used for that purpose. Some firms specialized in facilitating barter arrangements. Promissory notes issued by firms called veksels were frequently accepted, as well as debt swaps, and debt and tax offsets involving firms and local governments called zachety. However, even though many goods were used as temporary media of exchange, there are two distinguishing characteristics. First, none of them has been a nationwide generally acceptable medium of exchange and therefore cannot be considered money; and second, there has never been a credit market using any of these goods as units of accounts.

Firms were relatively successful using non-monetary transactions to acquire the inputs they needed to continue operating. Barter arrangements usually require firms to incur in transportation, storage, search and perishability costs. Since this paper is about explaining the quick emergence and fall of barter transactions in Russia, and whether this is the result of firms' choice, and not a theory of how barter operates, we avoid the complications of modeling such technology and assume that every firm wishing to

\footnotetext{
${ }^{4}$ Yeltsin and Gorbachev met during a barter of metal and timber from the Urals for food products from Stavropol.

${ }^{5}$ See Linz (2001)
} 
conduct barter transactions faces the same fixed barter cost $T$, if it needs to acquire inputs for a real value $L^{f}$.

\section{THE MODEL}

To forge a link with the credit rationing literature, we write a version of De Meza and Webb's (1987) credit rationing model to allow firms to decide whether to borrow cash or use barter to conduct transactions. All agents in this economy measure their financial wealth in units of foreign currency. This reflects the reality in many countries, especially in the developing world, that many people use a strong currency like the US dollar, the sterling pound, the euro or the yen as units of accounts to hedge against the instability of their own currencies. Thus, real variables can also be measured in units in foreign currencies.

Firms. There is assumed to be a continuum $[0,1]$ of risk-neutral firms. Each firm has an indivisible project, which yields a return $R_{i}^{s}$ with probability $q_{i}$, where $i$ is the index of the project. If the project fails, it yields a return $R^{f}$, which is common to all projects and can be zero. The distribution of $q_{i}$ across firms is characterized by the density function $g\left(q_{i}\right)$. The expected return $(R)$ is the same across projects, therefore

$$
q_{i} R_{i}^{s}+\left(1-q_{i}\right) R^{f}=R, \quad \text { for all } i .
$$

To undertake its project, each firm needs to conduct transactions for a real value of $L^{f}$. At the beginning of every period firms have no initial financial endowment; thus, if they want to conduct monetary transactions they have to borrow money. They have also some inventory in stock that either sell or can use for barter transactions.

First, consider a firm that borrows to conduct cash transactions. Loans are of a standard debt form. If the project succeeds, the firm repays the loan at an interest rate $r$ of 
local currency units. If it fails, it pays only the actual available return $R^{f}$. The expected return to the firm is

$$
E\left(\pi_{i}\right)=q_{i}\left[R_{i}^{s}-\left(\frac{1+r}{1+\varepsilon^{e}}\right) L^{f}\right],
$$

where $\varepsilon^{e}$ is the expected depreciation rate. Consider now a firm that engages in barter to conduct transactions. In this case, the firm sees its return decrease by the fixed barter cost $(T)$, and the expected return is

$$
E\left(\pi_{i}\right)=q_{i} R_{i}^{s}+\left(1-q_{i}\right) R^{f}-T .
$$

Assume that $T>L^{f}$ and

(4) $\quad R_{i}^{s}>T>R^{f}, \quad$ for all $i$.

From (2) and (3) observe that, when bartering, the firm faces the whole risk, whereas when asking for credit, only lenders assume risk. Firm $i$ will borrow if this allows it to obtain a higher expected return. This occurs if

$$
q_{i}<\frac{T-R^{f}}{(1+r) L^{f} /\left(1+\varepsilon^{e}\right)-R^{f}} .
$$

A higher barter cost makes the right-hand expression in (5) increase, and eventually, it will be greater than one, making barter unaffordable. This echoes the traditional literature, which considers barter so inefficient that it is always dominated by some medium of exchange. Assume that $T$ is small enough so that barter technology is feasible. Define $\mu(r)$ as follows:

$$
\mu(r)=\min \left\{\frac{T-R^{f}}{(1+r) L^{f} /\left(1+\varepsilon^{e}\right)-R^{f}}, 1\right\} \quad \mu_{r}<0, \mu_{\varepsilon}>0 .
$$

Then, $\mu(r)$ is the cutoff probability of success that makes a firm barter. Let $r_{b}$ denote the interest rate that makes the right-hand side in (5) equal to unity, then 


$$
r_{b}=\frac{T}{L^{f}}\left(1+\varepsilon^{e}\right)-1
$$

If $r<r_{b}, \mu=1$ and all firms conduct cash transactions, yet if $r>r_{b}$, firms with $q_{i}>\mu\left(r, \varepsilon^{e}\right)$ choose to barter. This means that only those firms with the riskiest projects remain in the credit market, making it even riskier. Similarly, higher expected depreciation means that the firm will pay a lower real interest; thus, firms will be willing to pay a higher nominal interest for a loan.

The Demand for Credit. From (5) and (6), firm $i$ will ask for a loan if $q_{i}<\mu\left(r, \varepsilon^{e}\right)$. In addition to firms, the government also participates in the credit market by issuing bonds $\left(L^{g}\right)$ to finance it purchases. Thus, the total real demand for credit $\left(L^{d}\right)$ is simply

$$
L^{d}=L^{g}+L^{f} \int_{0}^{\mu} g\left(q_{i}\right) d q_{i} .
$$

When $r \leq r_{b}$, all firms conduct cash transactions, and the demand for credit is constant and equal to $\left(L^{g}+L^{f}\right)$. However, as the interest rate surpasses $r_{b}, d \mu / d r<0$, a share of firms switches to barter, and the demand for credit decreases. Thus, from the discussion above, (6) and (8) the following lemma is apparent.

Lemma 1: The demand for credit function is

i) increasing with respect to government borrowing;

ii) constant and equal to $\left(L^{g}+L^{f}\right)$ if $r \leq r_{b}$, and a decreasing function with respect to $r$ if $r>r_{b}$. 
The Supply of Funds. There is a continuum $[0,1]$ of lenders who are the sole holders of financial wealth. The expected real payoff to a lender that makes a firm a loan is ${ }^{6}$

$$
E\left(\pi_{b}\right)=\left(\frac{1+r}{1+\varepsilon^{e}}\right) L^{f} \int_{0}^{\mu\left(r, e^{e}\right)} q_{i} g\left(q_{i}\right) d q_{i}+R^{f} \int_{0}^{\mu\left(r \cdot \varepsilon^{e}\right)}\left(1-q_{i}\right) g\left(q_{i}\right) d q_{i} .
$$

By differentiating (9) with respect to $r$ we obtain the impact of an increase in the interest rate on the expected return of the lender that is making the loan:

$$
\begin{aligned}
& \frac{d E\left(\pi_{b}\right)}{d r}=L^{f} \int_{0}^{\mu} q_{i} g\left(q_{i}\right) d q_{i}+\frac{d \mu}{d r}\left[(1+r) L^{f} \mu g(\mu)+R^{f}(1-\mu) g(\mu)\right] \\
& \frac{d E\left(\pi_{b}\right)}{d \varepsilon^{e}}=\left[\frac{1+r}{1+\varepsilon^{e}} \mu L^{f}+R^{f}(1-\mu)\right] g(\mu) \frac{d \mu}{d \varepsilon^{e}}-(1+r) L^{f} \frac{\int_{0}^{\mu\left(r, \varepsilon^{e}\right)} q_{i} g\left(q_{i}\right) d q_{i}}{\left(1+\varepsilon^{e}\right)^{2}}
\end{aligned}
$$

The first term on the right-hand side in (10a) reflects the higher expected repayment because of the higher interest. For $r \leq r_{b}$, all firms borrow, so $d \mu / d r=0$ and the lender's expected profits is an increasing function of the interest rate. Yet, for $r>r_{b}, d \mu / d r<0$, the first term becomes smaller, and the second term turns negative and increases in absolute value, reflecting the deterioration in the quality and quantity of borrowers, which affects negatively the lender's expected profits. Eventually, $d E\left(\pi_{b}\right) / d r$ will turn negative, which means that $E\left(\pi_{b}\right)$ reaches a maximum at some interest rate $r^{*}$.

Consider now the effect of the expected exchange rate. The first term in (10b) is positive, and reflects the indirect effect of the exchange rate on the number of firms that remains in the credit market. On the other hand, the second term represents the direct effect that the lower real return has on the expected repayment, and is clearly negative.

\footnotetext{
${ }^{6}$ For the sake of simplicity, we assume that the distribution $G$ for the riskiness variable $q$ adds to one. Ontherwise, this expression should be divided by $G$.
} 
Although in general this derivative can be either positive or negative, it is reasonable to think that the second term dominates, and we will assume this in the rest of the paper.

Let $\rho_{l}$ denote the expected real return to an individual lender. Thus, $\rho_{l}=E\left(\pi_{b}\right) / L^{f}$. We identify two possible graphical representations of $\rho_{l}$. Figure 2 a shows the case where $\rho_{l}$ decreases immediately after the interest rate reaches the turning point to barter, therefore $r_{b}=r^{*}$, and Figure $2 \mathrm{~b}$ shows the case where $\rho_{l}$ keeps increasing after the interest rate reaches $r_{b}$. The exact shape will depend on the density function, $g\left(q_{i}\right)$, and the barter cost $T$. If most firms conduct very safe projects, they switch to barter as soon as the interest rate reaches the turning point $r_{b}$. To hedge against the increasing risk, lenders will not set higher interest rates and barter results from credit rationing. On the other hand, given the density function, $g\left(q_{i}\right)$, a higher barter cost increases the interest rate, which makes firms turn to barter.

Equilibrium. Let $C(L)$ denote lenders' cost if they lend real funds for an amount $L$, where $C^{\prime}>0, C^{\prime}>0$. Lenders obtain an expected real return $\rho_{l}$ for loans awarded to firms. Assume that loans to the government are riskless; thus, lenders' expected profit is

$$
E\left(\Pi_{l}\right)=\rho_{l}\left(L-L^{g}\right)+\frac{1+r}{1+\varepsilon^{e}} L^{g}-C(L) .
$$

Assume that lenders are risk-neutral institutions that supply funds up to the point at which their expected return equals the marginal cost of funds $(C)$, that is,

$$
\rho_{l}=C^{\prime}(L),
$$

that is, the supply of funds is an increasing function of $\rho_{l}$. Figure 3 shows the shape of the supply of funds curve. It resembles the diagram used by Stiglitz and Weiss (1981). The 
fourth quadrant presents $\rho_{l}$ as shown in Figure $2 \mathrm{~b}$. The third quadrant shows the supply of funds, and the second quadrant shows a $45^{\circ}$ line. Thus, the first quadrant shows the implied supply of funds as a function of the real interest rate $r$. Similarly, we can obtain the supply of funds curve if $\rho_{l}$ takes the shape shown in Figure 2a. Suppose that government bonds are just as risky as the whole portfolio of loans to firms. Since the set of lenders is a continuum $[0,1]$, the curve in the first quadrant of Figure 3 also represent the aggregate supply of funds curve.

Lemma 1 allows drawing the demand for credit function (8) as shown in Figures 4, 5 and 6 . We consider three cases. First, equilibrium when $r_{b}=r^{*}$; second, equilibrium when $r_{b}<r^{*}$; and third the impact of an increase in the expected depreciation rate.

Case $1\left(r_{\underline{b}}=r^{*}\right)$ : This case is illustrated in Figure 4. If the sum of the government's borrowing and firms' investment requirement is small enough, say $\left(L^{g}+L^{f}\right)_{0}$, the only stable equilibrium is point $A$. The equilibrium interest rate will be set below the turning point $r^{*}$, lenders will fully satisfy the demand for credit and no firm will barter.

Suppose now that the credit requirement strongly increases to $\left(L^{g}+L^{f}\right)_{1}$. At this demand level, lenders are not willing to increase the interest rate beyond $r_{b}$ and there will be credit rationing. This is the typical credit rationing equilibrium. In this case, those firms subject to credit rationing will have no other choice but to barter.

Case $2\left(r_{\underline{b}}<r^{*}\right)$ : This case is illustrated in Figure 5. As in case 1, if $\left(L^{g}+L^{f}\right)_{0}$ is small enough, the only stable equilibrium is point $A$. In this case the demand for credit is fully satisfied and there is no barter. However, as the credit requirement increases, the interest rate keeps increasing until eventually it surpasses the turning point $r_{b}$. If equilibrium is set at point $B$, then the interest rate is higher than $r_{b}$ but lower than $r^{*}$, lenders fully satisfy 
the demand for credit, but those firms whose probability of success is greater than $\mu(r)$ will be better off if they quit the credit market and conduct barter transactions. In this equilibrium barter is not due to credit rationing but is the choice of some firms.

Suppose that the credit requirement keeps increasing until the demand for credit

curve reaches $L_{2}{ }^{d}$. Since lenders will not increase the interest rate beyond $r^{*}$, there will be credit rationing. In this case, there will be firms bartering for two different reasons. Those firms with probability of success $q_{i}>\mu\left(r^{*}\right)$ choose to barter, but some others barter because of lack of credit.

Case 3 (expected depreciation rate): Of special interest is to analyze the effect of an increase in the expected depreciation rate. Since lenders measure their financial wealth in foreign currency units, the expected real return in foreign currency is $\rho_{l}=E\left(\pi_{b}\right) /\left(L^{f} \varepsilon^{e}\right)$.

For a given interest rate, an increase in the expected depreciation rate reduces $\rho_{l}$ so the aggregate supply of funds curve shrinks, as shown in Figure 6. Suppose that initially there is a barter equilibrium at point $A$. The increase in the expected depreciation rate makes lenders increase the interest rate, the new equilibrium is set at point $B$, and some firms choose to barter. If equilibrium is initially at point $C$, it causes an increase in barter because some firms choose to do it, but also because of credit rationing.

\section{EXPLAINING THE FACTS}

The monetary policy in Russia experienced major changes from 1994 on, after the high inflation episode of the early 1990s. Figure 7 illustrates this policy change. The government debt to commercial banks kept increasing from the end of 1994 until mid1999. On the other hand, the monthly inflation rate decreased from about $17 \%$ at the end 
of 1994 to lower than $1 \%$ by the end of the decade. This signals that an important share of the government's finance switched from seigniorage to debt with the private sector.

Let us use the model developed above to explain the two stylized facts mentioned in the introduction. Firms in Russia have access to barter technology as a legacy from the Soviets. The lower money growth rate made inflation decrease, and together with the increasing government debt, it created an upward pressure on the real interest rate that caused firms to increasingly give up money to conduct transactions, hence making barter activity steadily increase. This explains the negative correlation of the use of barter and both money growth and inflation rates.

On the other hand, as the monetary conditions worsened during the late 1990s, lenders intuited a higher probability of currency collapse which materialized in the Russian currency crisis of September 1998. The higher expected depreciation was another factor that made lenders withdraw from the market, pushing the real interest rate up and fostering barter transactions. After the collapsed, the expected depreciation effect suddenly vanished, and an increasing amount of financial resources were injected into the Russian economy. The expected real interest rate decreased and firms started returning to cash transactions. This explains why barter increased during the 1990s but has decreased from the end of the decade on, right after the September 1998 collapse.

\section{CONCLUSION}

Barter is a transaction technology available even in modern economies. Under stable monetary conditions, evidence shows that the optimal level of barter transactions is small relative to the total number of cash transactions. However, this does not seem to be the case of Russia during the 1990s, where barter reached more than half of total transactions 
among firms in an environment of monetary instability, and fell to about $10 \%$, two years after the ruble collapse in 1998. This paper offers a monetary model to explain the phenomenon. The credit market progressively became tighter for two reasons: the switch from seignorage to borrowing as a source of government financing; and lenders' withdrawal from the market as the economy's fragility increased. This pushed firms to look for alternative transaction technologies, i.e., barter. Yet, after the ruble collapse, the credit market loosened and barter declined.

This paper also approaches the question of whether barter results from credit rationing or firms' optimal decision when the credit market becomes tighter. Given the distribution of risk across firms, we find three possible equilibria. First, if barter technology is very costly, firms remain in the credit market until they are subject to rationing, and barter is a Hobson's choice. Second, if barter is a much more affordable technology, a tight credit market makes the less risky firms choose barter and there will not be credit rationing. Yet if, as in the third scenario, the market becomes even tighter, some credit rationing appears and we obtain an equilibrium in which barter is the optimal choice of the less risky firms and a Hobson's obtains choice for some riskier ones. It remains to determine what kind of equilibrium occurred in Russia. The answer to that question should be subject to empirical studies, which is not the goal of this paper. However, the model shown above proposes a testable theory. If the interest rate affects the share of barter transactions, the interest rate channel of transmission from monetary policy to barter is working, that is, if barter responds to higher interests, then it is the result of individuals' choice. If it does not, it is the result of credit rationing, and in this 
case it should respond to the variable(s) causing the monetary constraint. Yet, the empirical answer to this problem is a matter of further research.

An interesting extension of this paper is to consider emergence of barter transactions in the context of the firm's decision about internal finance or external finance. This would provide links between barter and the corporate finance literature. However, this approach is far beyond the goal of this paper.

\section{REFERENCES}

Bevan, A., S. Estrin, B. Kuznetov, M. Schaffer, M. Angelucci, J. Fennema and G. Mangiarotti (2001) "The Determinants of Privatized Enterprise Performance in Russia," William Davison Working Paper Number 452, Jun.

Blanchard, O. and M. Kremer (1997) "Disorganization," Quarterly Journal of Economics, November, 112-4, pp. 1091-1126.

Brana, S. and M. Maurel (2000) "Barter in Russia : Liquidity Shortage Versus Lack of Restructuring," William Davison Institute at the University of Michigan, Working Paper number 271 .

Commander, S., I. Dolinskaya and C. Mumssen (2000) "Determinants of Barter in Russia - An Empirical Analysis," International Monetary Fund Working Paper 00/155. October.

De Meza, David and David C. Webb (1987). “Too Much Investment: A problem of Asymmetric Information," Quarterly Journal of Economics 102 (2), May: 281292.

Ellingsen, Tore (1998) "Payments in Kind," Working Paper Series in Economics and Finance, No. 244, Stockholm School of Economics, 1998 (revised 2000). 
Ellingsen, Tore and Lars A. Stole (1996) "Mandated Countertrade as Strategic Commitment," Journal of International Economics, Vol. 40(1), February, 67-84.

Gaddy, Clifford and Barry Ickes (1999) "An Accounting Model of the Virtual Economy in Russia," Post-Soviet Geography and Economics, March, 40(2): 79-97.

Hendley, Kathryn, Barry Ickes and Randi Ryterman (2000) "Remonetizing the Russian Economy" Discussion Paper, no. 400. Russian enterprise reform: Policies to further the transition Washington, D.C.: World Bank, 1999; 101-20.

Keeton, William (1979). “Equilibrium Credit Rationing,” New York: Garland Press.

Kindleberger, C. P. (1993) “A Financial History of Western Europe.” Oxford University Press, Second Edition.

Kiyotaki, N. and R. Wright (1989). "On Money as a Medium of Exchange. "Journal of Political Economy, vol. 9, no. 41.

Kiyotaki, N. and R. Wright (1993). "A Search Theoretical Approach to Monetary Economics.” American Economic Review, March, vol. 83(1): 63-77.

Linz, Susan J. (2001) "Restructuring with What Success? A Case Study of Russian Firms" Comparative Economic Studies, 43(1), Spring, pages 75-99.

Linz, S. and G. Krueger (1998) "Enterprise Restructuring in Russia's Transition Economy: Formal and Informal Mechanisms" Comparative Economic Studies, 40(2), Summer 1998, pages 5-52.

Makarov, V. and G. Kleiner (2000) "Barter in Russia: An Institutional Stage" Problems of Economic Transition 42(11), March, pages 51-79.

Marin, Dalia and Monika Schnitzer (1995) “Tying Trade Flows: A theory of countertrade and evidence," American Economic Review December, vol. 85(5), 1047-1064. 
Marin, Dalia and Monika Schnitzer (1999) "The Economic Institution of International Barter,” Economic Journal April 2002; 112(479): 293-316.

Prendergast, Canice and Lars Stole (1999) "Restricting the Means of Exchange Within Organizations," European Economic Review, April, vol. 43, no. 4-6: 1007-1019.

Prendergast, Canice and Lars Stole (2001a) "The Non-Monetary Nature of Gifts," European Economic Review, December, vol. 45, no. 10: 1793-1810.

Prendergast, Canice and Lars Stole (2001b) "Barter, Liquidity and Market Segmentation," unpublished manuscript, University of Chicago.

Stiglitz, Joseph and Andrew Weiss (1981) "Credit Rationing in Markets with Imperfect Information.” American Economic Review 71, 3 (June), 393-410.

Trejos, Alberto and Randall Wright (1991). "Search, Bargaining, Money and Prices," Journal of Political Economy, February, vol. 103(1): 118-141. 
TABLE 1

\begin{tabular}{|l|l|}
\hline Correlation barter share - money growth rate & -0.52 \\
\hline
\end{tabular}

Correlation barter share - inflation $-0.63$

Source: IFS/IMF (money growth rate and inflation)

Russian Economic Barometer (Barter share)

Sample size: 125

Monthly data from February 1992 to June 2002

FIGURE 1

Barter and Depreciation Rate in Russia (1992-2003)

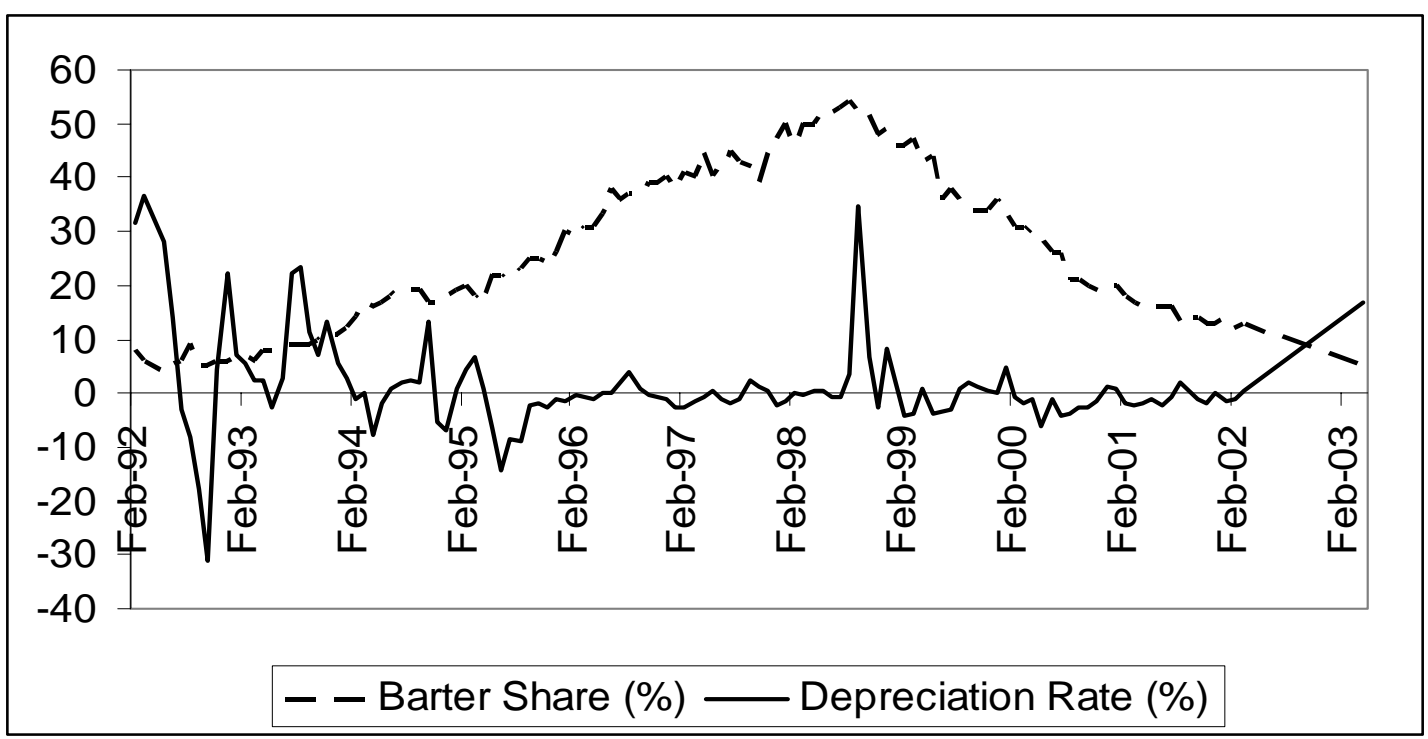

Source: IFS/IMF (real exchange rate depreciation rate)

Russian Economic Barometer (Barter share) 


\section{FIGURE 2}

\section{The Expected Payoff to Lenders}

(a)

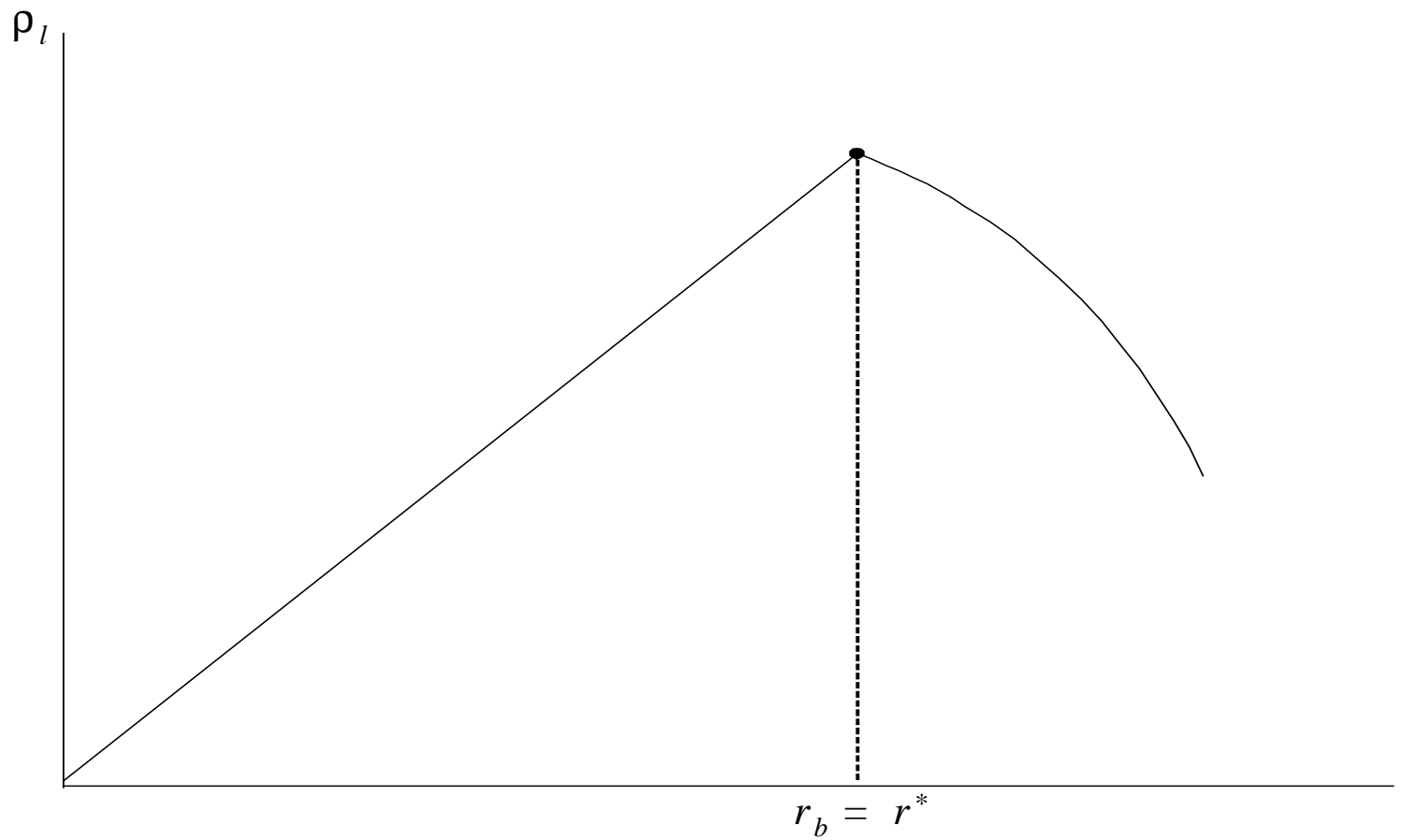

(b)

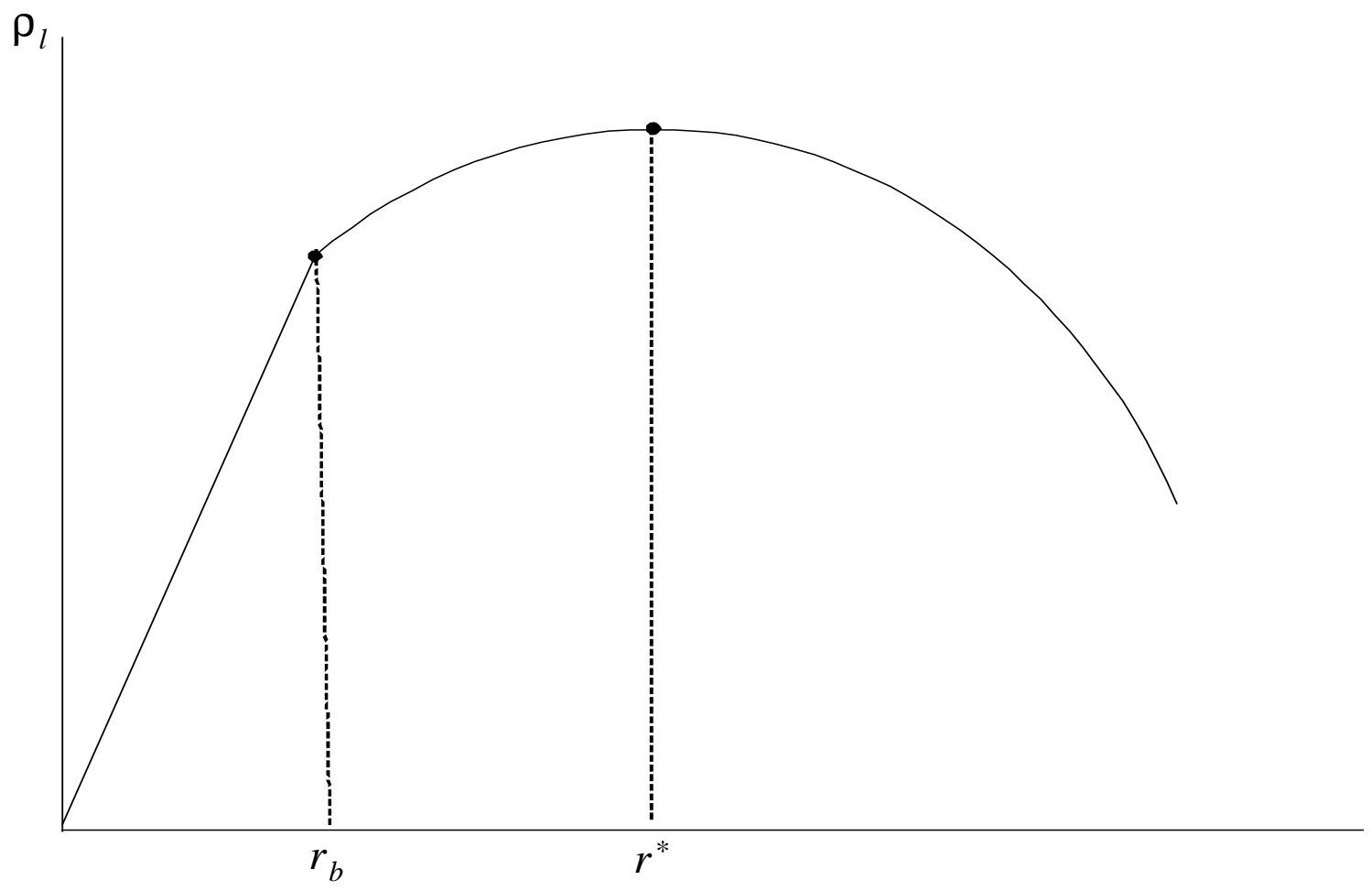


FIGURE 3

The Supply of Funds Curve

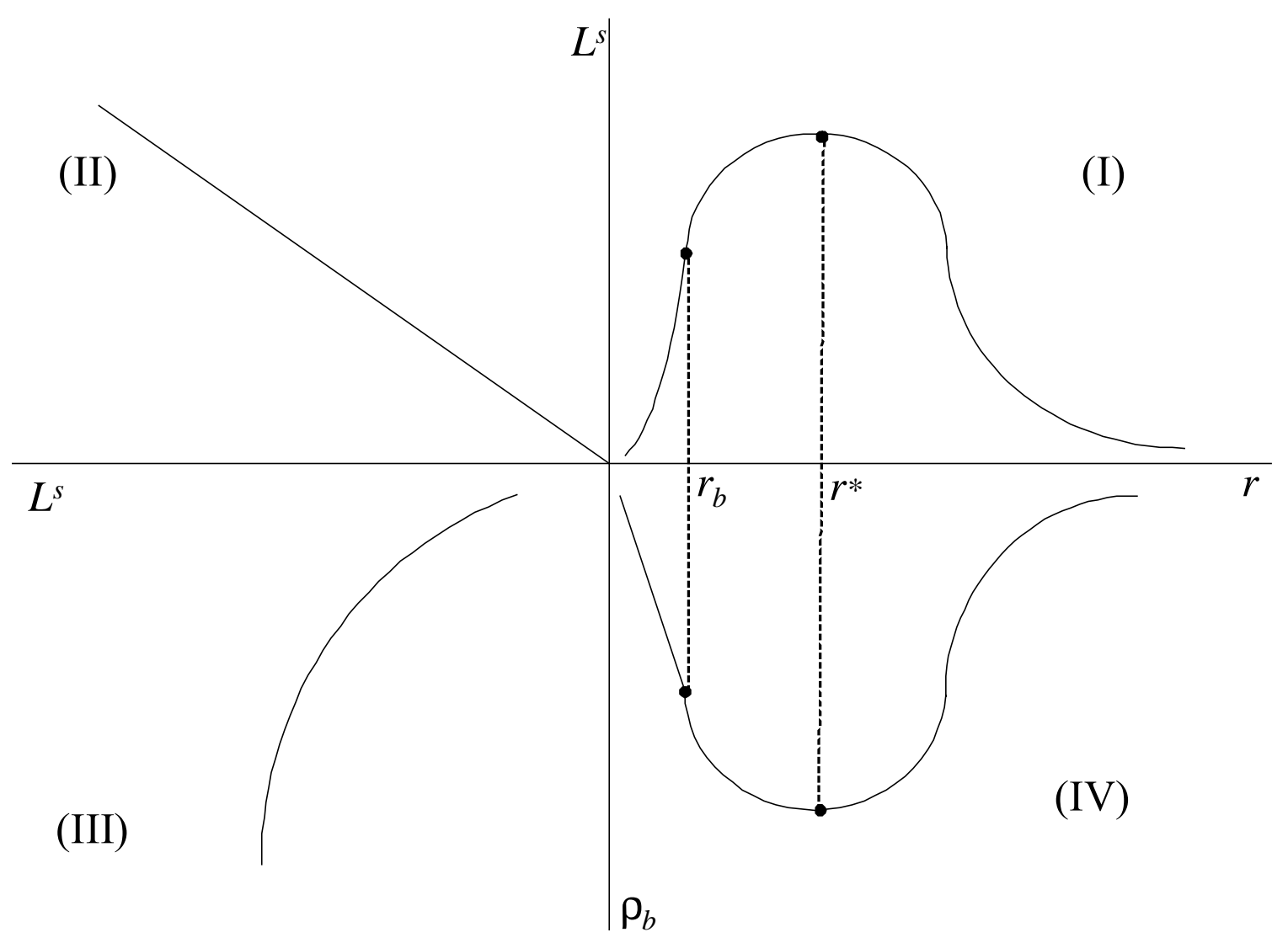


FIGURE 4

Equilibrium $r_{b}>r^{*}$

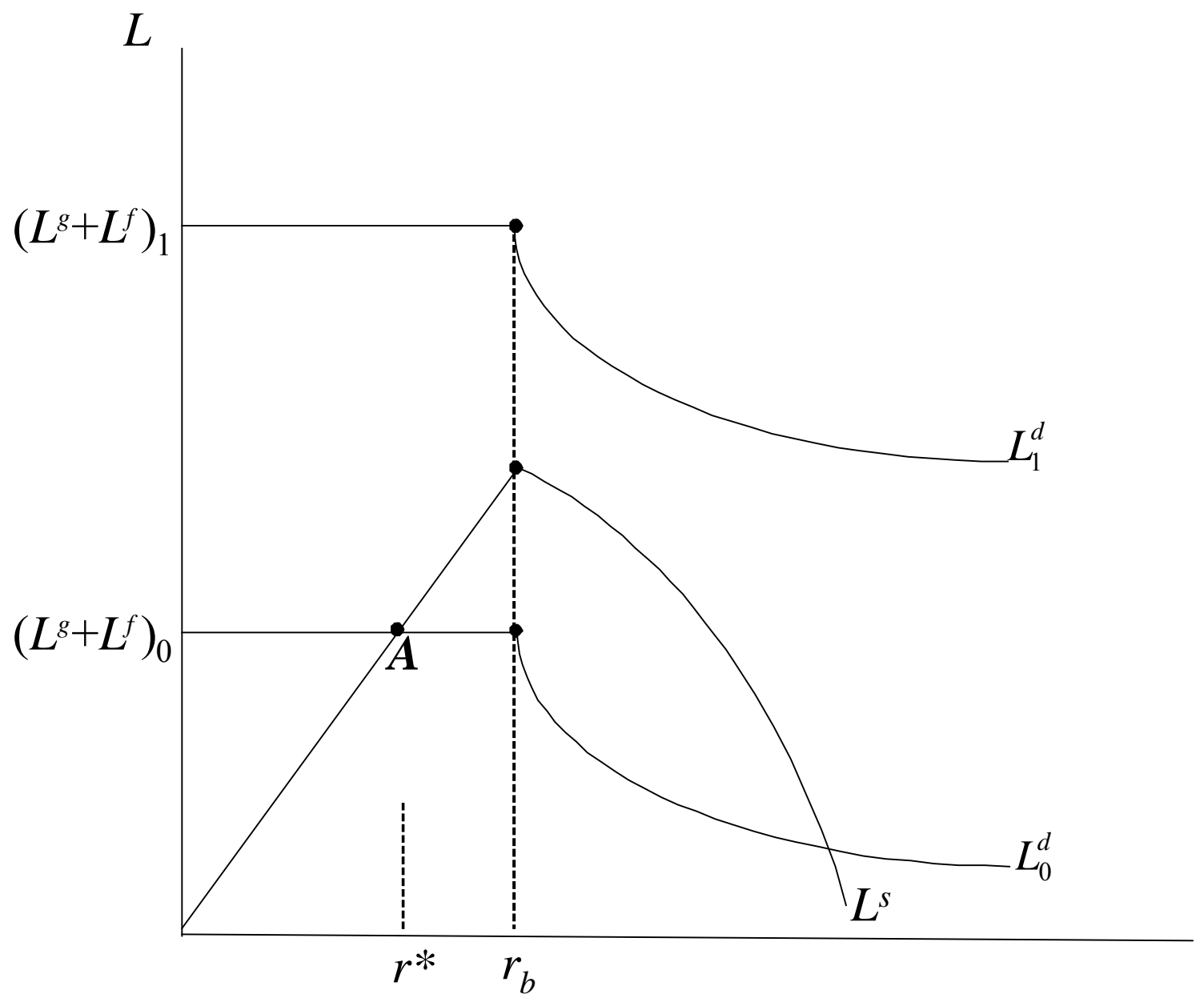


FIGURE 5

Equilibrium $\boldsymbol{r}_{\boldsymbol{b}}<\boldsymbol{r}^{*}$

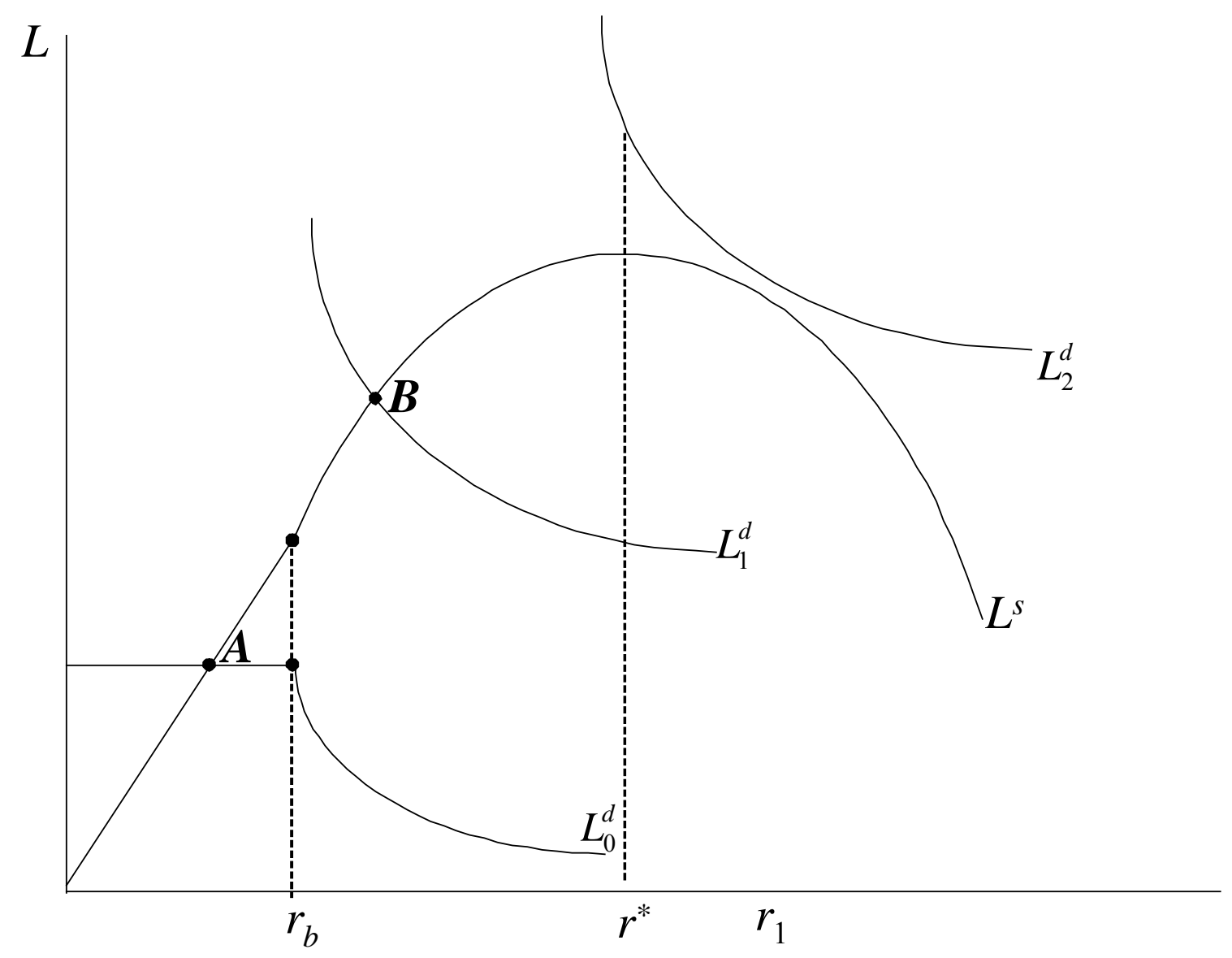


FIGURE 6

An Increase in the Expected Depreciation Rate

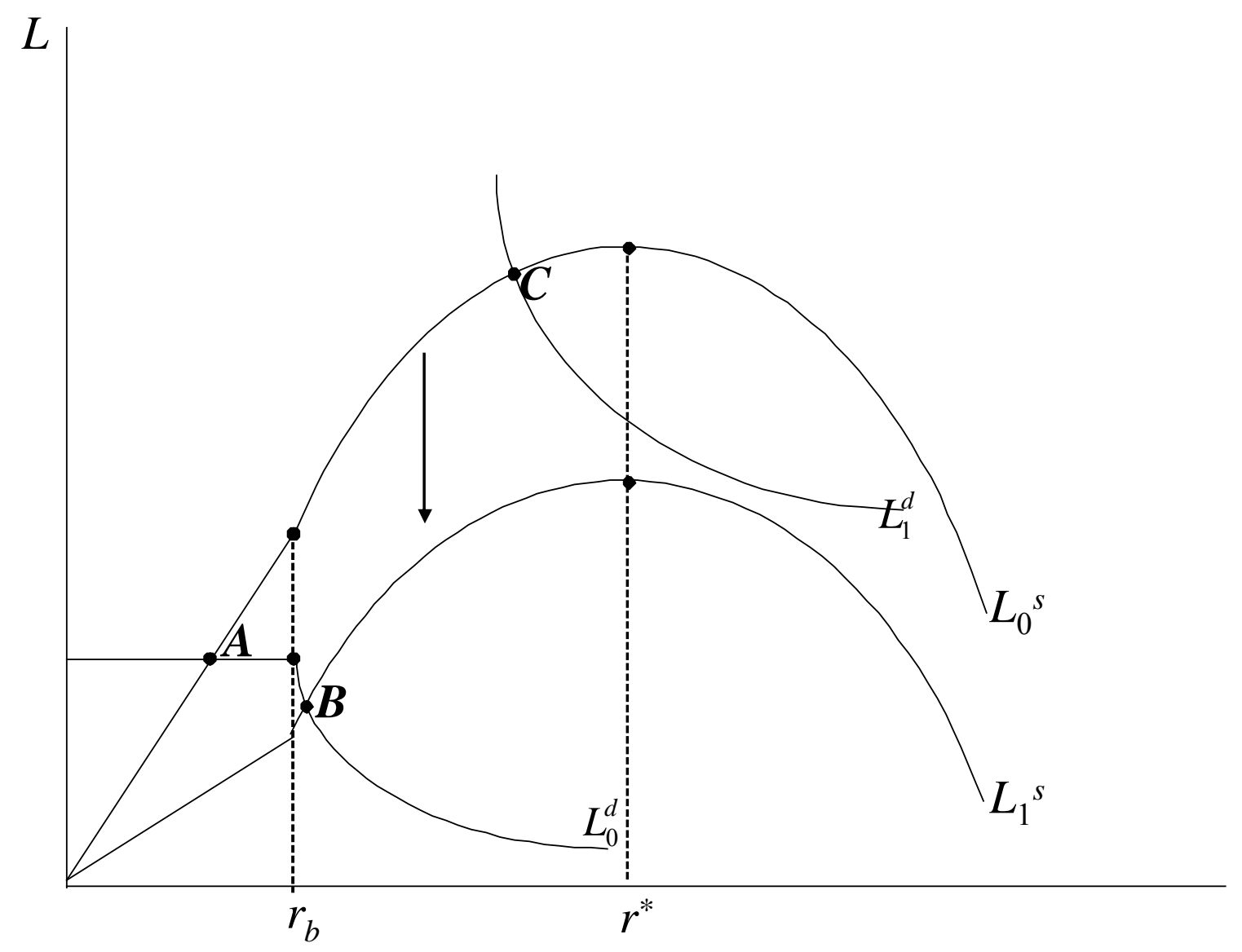




\section{FIGURE 7}

\section{Real Government Debt to Commercial Banks in Russia}

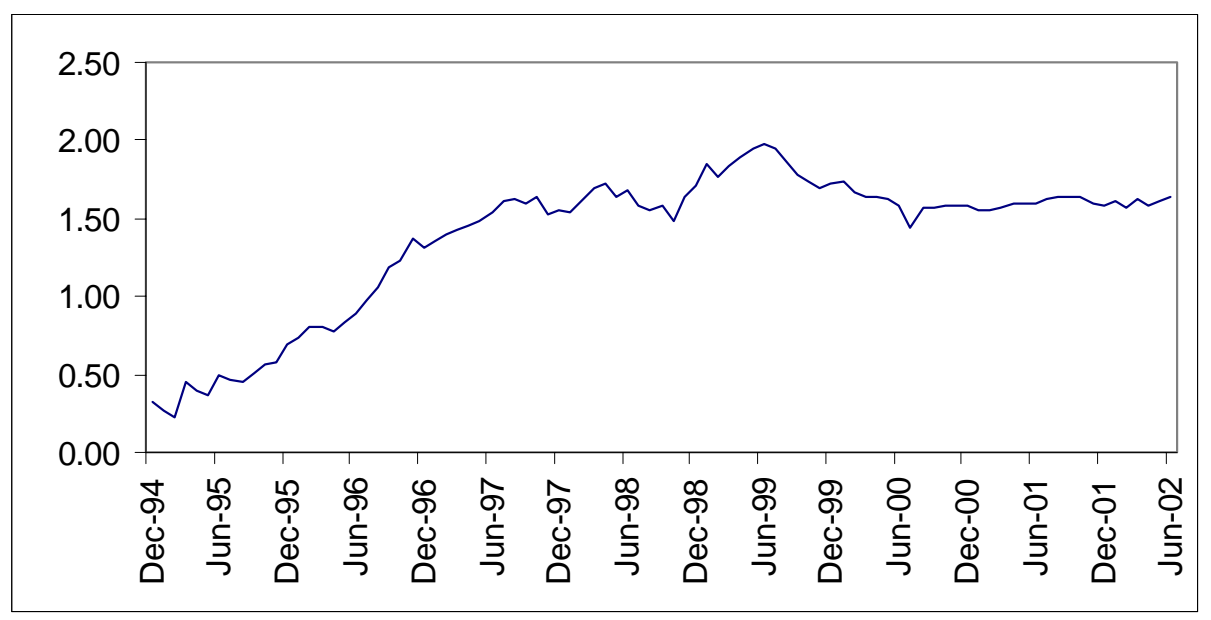

Source: Russian Economic Trends 
CERGE-EI

P.O.BOX 882 Politických vezòù 7

11121 Prague 1

Czech Republic http://www.cerge-ei.cz 